\title{
On Some Petrified Plants from the Cretaceous of Chôshi, Chiba Prefecture V.*
}

\author{
by Makoto NiSHIDA**
}

Received September 7, 1967

\begin{abstract}
Four species of petrified woods from the Cretaceous of Chôshi have been described as a consecutive work from the previous papers. Three species out of them would be new to science: Brachyoxylon nipponicum sp. nov., Planoxylon choshiense sp. nov. and Protocedroxylon japonicum sp. nov. The fourth, Araucarioxylon sp., closely resembles $A$. kiiense Ogura in general structures except for rays and arrangement of bordered pits on tangential walls of tracheids.

This paper contains the description of the following four species:

21.*** Brachyoxylon nipponicum sp. nov. No. 6328

22. Planoxylon choshiense sp. nov. Nos. $6606 \& 6608$

23. Protocedroxylon japonicum sp. nov. No. 6414

24. Araucarioxylon sp. No. 6609
\end{abstract}

\section{Brachyoxylon nipponicum sp. nov. (Fig. 1, Plate I)}

No. 6328 is a piece of secondary wood, $5 \mathrm{~cm}$ long and $2 \times 10 \mathrm{~cm}$ in diameters, and remarkably well preserved.

Description. Coniferous wood. Growth ring distinctly visible by the broad early wood and narrow, 2 cell-layered late wood. Tranisition from the early to the late wood abrupt. Wood consists only of tracheids and rays, and devoid of wood parenchyma. No resin canal is found. Tracheids occluded with black resinous substances sparsely scatter throughout the wood and appear seemingly to be wood parenchyma. Tracheids regularly arranged in radial rows, somewhat radially elongated rectangular in the cross section, $50-75 \mu$ and $65-78 \mu$ in tangential and radial diameters respective1y. Cell walls thick, especially in radial walls, $12-17 \mu$ in thickness. Bordered pits on radial walls of tracheids circular or somewhat flattened hexagonal, contiguously or sometimes separately arranged in two, rarely one, rows, and if in two rows, pits are hexagonal and alternately arranged, or often circular and oppositely arranged. Pits are $20-24 \mu$ in diameter, with circular or ovoid pit apertures of $8-10 \mu$ in diameter. Bordered pits on tangential walls somewhat smaller and circular and contiguously or separately arranged in 1-2 rows. Rims of Sanio not visible. Rays all parenchymatous, generally uniseriate and biseriate in part, 5-16 cells high, sometimes exceptionally $1-3$ and 22 cells high, and run at intervals of $1-9,4.3$ on an average, rows

* Contributions from the Laboratory of Phylogenetic Botany, Chiba University, No. 41. Supported by a Grant in Aid of Scientific Research of Ministry of Education, No. 407045.

** Laboratory of Phylogenetic Botany, Foreign Students' College, Chiba University, Yayoicho 1 , Chiba.

*** The consecutive number from the previous paper ${ }^{1)}$. 
of tracheids. Ray cells are somewhat vertically or horizontally elongated rectangular or broadly ovoid in shape in tangential sections, $17-30 \mu$ and $17-32 \mu$ in horizontal and vertical diameters, some of them filled by black substances. Horizontal and tangential walls thick and smooth and abietineous pittings not visible. Pits on radial walls bordered or half bordered, $3.5-4.5 \mu$ in diameter, and $6-20$ pits, with pit aperture of lenticular form, crowded in a cross field and contiguously arranged in 2-3 rows.

Affinity. Although this species seems to relate closely with Araucariaceae in having contiguously and alternately arranged bordered pits on the radial walls of tracheids and absence of wood parenchyma, it has also separately arranged bordered pits on radial walls. Moreover presence of bordered pits on tangential walls is contradictory with the characters of Araucariceae in a strict sense. Including above mentioned characters, crowded small bordered or half bordered pits in the cross field agree with diagnostic characters of the genus Brachyoxylon (Hollick and Jeffrey ${ }^{2)}$ ). Generally there are traumatic resin canals in Brachyoxylon. But any resin canals are not found in the present specimen. This specimen most resembles B. notabile Torrey ${ }^{32}$ among the species registered in this genus, but differs from it in having usually biseriately and contiguously arranged bordered pits instead of uniseriately and separately arranged pits. Moreover the present species has higher, 5-15 cells high, rays, whereas $B$. notabile exhibits lower, 2-3 cells high, ones. Pits in a cross field are also different from each other: $B$. notbaile has several separate pits. B. raritanense Torrey ${ }^{3)}$ also very closely resembles the present species in general structures except for the following respects : ray cell of the former have 1-9 oculipores in each cross field and its tracheids are not sculptured by biseriate bordered pits. B. comanchense Torrey ${ }^{3)}$ differs from the present species in the state of cross field and rays: as it has no crowded pits but separately arranged ones in the cross field and has lower rays of 1-6 cells in height. B. woodworthianum was firstly described by Torrey ${ }^{3}$ from North America and also reported by Shimakura ${ }^{4)}$ from the Cretaceous of Iwate Prefecture. This species, however, also differs from the present species in the occasional occurrence of very high rays reaching up to 50 cells in height. In addition, it has

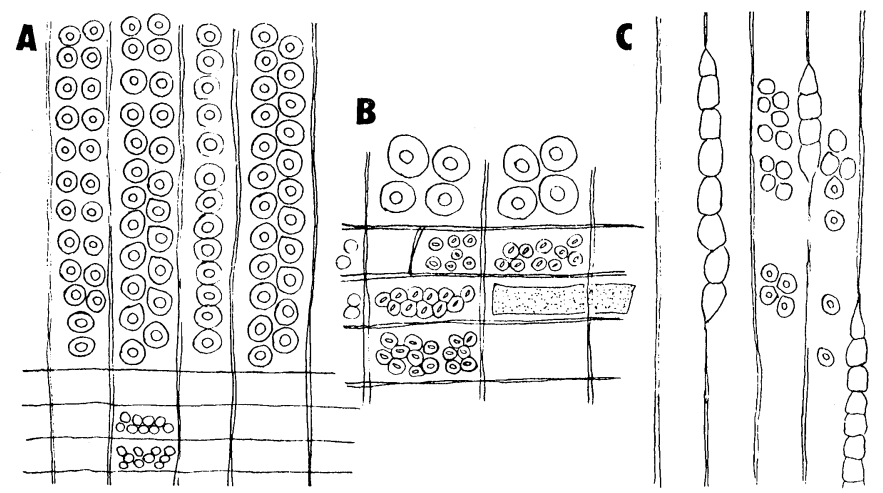

Fig. 1. Brachyoxylon nipponicum sp. nov.

A \& B : radial sections. C: tangential section. B is a magnified figure of the cross fields bearing crowd half bodered pits. Tangential walls of tracheids often have also brachyoxylic bordered pits. 
fewer number of pits in the cross fields. The present specimen would be new species belonging to the genus Brachyoxylon.

22. Planoxylon choshiense sp. nov. (Fig. 2, Plate II)

No. 6608 is a small twig, $4.7 \mathrm{~cm}$ long and $2.5 \mathrm{~cm}$ in diameter, consisting of secondary woods. No. 6606 is a piece of secondary wood, $6.5 \mathrm{~cm}$ long and $3.5 \mathrm{~cm}$ in diameter and well preserved.

Description. Growth rings not visible. Woods consist of tracheids, rays and a few wood parenchyma. Resin canals not present. Tracheids rectangular or more or less radially elongated rectangular in cross section, $22-35 \mu$ and $22-40 \mu$ in tangential and radial diameters and regularly arranged in radial rows. Bordered pits on radial walls contiguously and alternately arranged usually in two rows and sometimes in one or three rows, circular and somewhat flattened and variable in size, and 15-18 $\mu$ in diameter; exhibit typical araucarian type of pitting. Smaller bordered pits on tangential walls also contiguously and alternately arranged in one to two rows. Rays all parenchymatous, uni- or biseriate, sometimes triseriate in part, 4-15 cells high, sometimes 38 cells high in extreme cases. Ray cells vertically elongated ovoid in tangential section, ca. $23 \mu$ and $12-17 \mu$ in vertical and horizontal width.. Tangential and horizontal walls of ray cells pitted by small simple pits, i. e. abietineous pitting present. Pits in a cross field are usually single, sometimes two arranged horizontally, and half bordered, elliptical in outline, and $10-17 \mu$ in major diameter. Wood parenchyma sparsely scattered among tracheids, vertical walls sparsely pitted by small simple pits of $2-4 \mu$ in diameter.

Affinity. We can easily understand that the present specimens would belong to Planoxylon, as they exhibit araucarian type of bordered pit, abietineous pitting on ray cells, large one to two pits in a cross field and sparsely scattered wood parenchyma. This species differs from P. Hectori Stopes ${ }^{5)}$ from the Cretaceous of
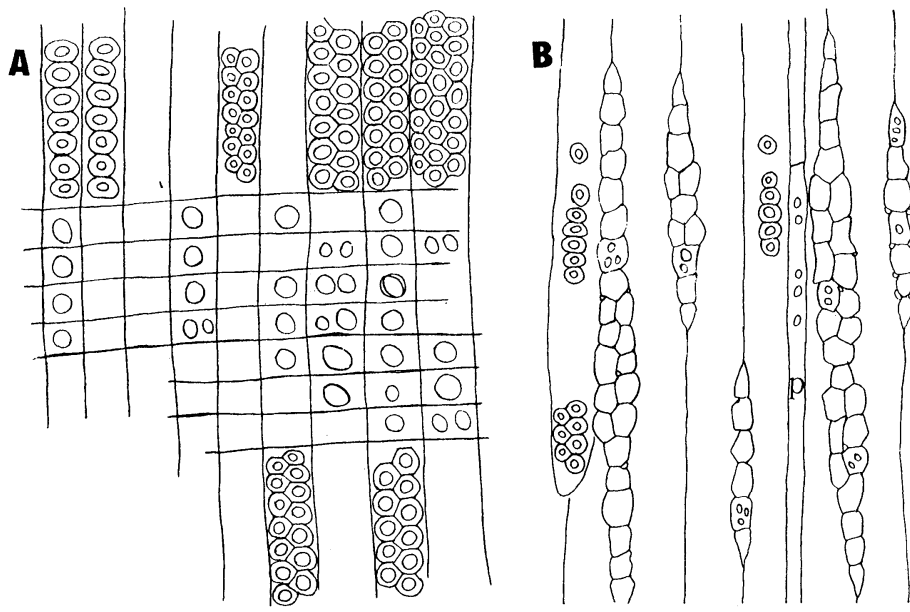

Fig. 2. Planoxylon choshiense sp. nov.

A : radial section. $\mathrm{B}$ : tangential section; $\mathrm{p}$ : wood parencyma. Partially contiguous bordered pits appear on tangential walls of tracheids. 
New Zealand and $P$. pseudo-Hectori Nishida ${ }^{6}$ from the same locality where the present specimens were collected, in having broader, usually biseriate, sometimes triseriate, rays instead of usually uniseriate rays, and horizontally arranged two or one pits in a cross field instead of vertically arranged two pits. This species also differs from P. Lindlerii (Witham.) Stopes ${ }^{5)}$ from the Cretaceous of England in having no resin canals which appears in the latter, and from $P$. Inaii Shimakura ${ }^{4}$ from the Upper Cretaceous of Saghalien in having large two or one pit in a cross field instead of several small pits in the latter. The present species is also unique one in having contiguously arranged bordered pits on tangential walls of tracheids and in this respect, this will be distinguished from other species of the genus.

23. Protocedroxylon japonicum sp. nov. (Fig. 3, Plate III)

No. 6614 is a piece of woods, $5.5 \mathrm{~cm}$ long and $3.2 \mathrm{~cm}$ in diameter, consisting of tracheids and rays and without wood parenchyma and resin canal.

Description. Growth rings not visible. Tracheids variable in size; smaller ones are $10-12 \mu$ and larger ones are $25-33 \mu$ in diameters, almost square or slightly tangentially elongated rectangular in cross section. Some tracheids occluded with black resinous substances and seemingly appear to be wood parenchyma and some others often have cross septa. Bordered pits on radial walls circular, $12-15 \mu$ in diameter, with pit apertures of $3-5 \mu$ in diameter, contiguously or often separately arranged in one row in general cases and if in two rows, they are alternately disposed. Rims of Sanio not visible. Somewhat smaller circular, $11-13 \mu$ in diameter, bordered pits contiguously disposed on tangential walls of tracheids. Rays all parenchymatous,

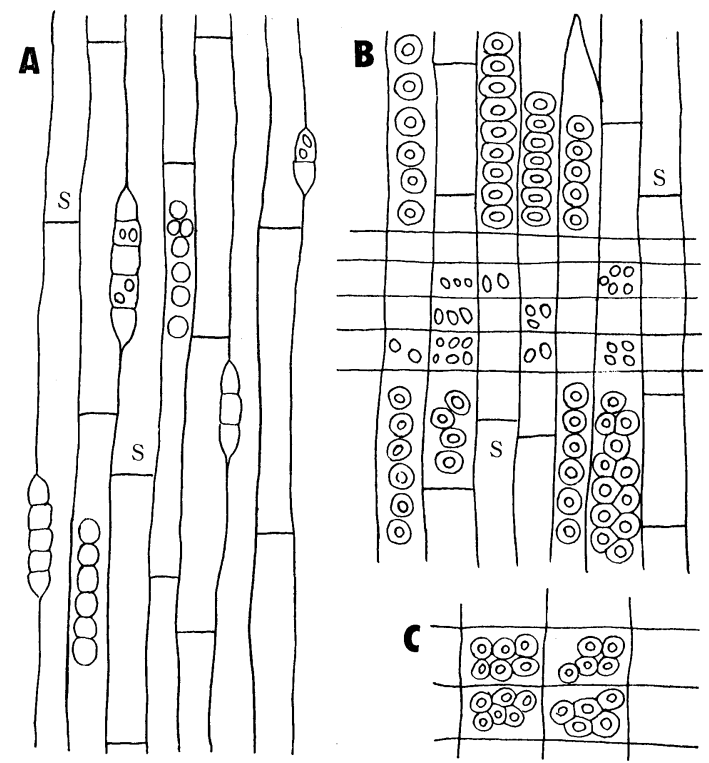

Fig. 3. Protocedroxylon japonicum sp. nov.

A: tangential section. $\mathrm{B} \& \mathrm{C}$ : radial sections; $\mathrm{s}$ : tracheids with cross septa. $\mathrm{C}$ is a magnified figure of the cross field bearing crowd several bordered pits. 
always uniseriate, usually $1-4$, rarely 6 cells high and run at intervals of 2-11, 5.4 on an average, rows of tracheids. Ray cells variable in size, sometimes vertically and sometimes horizontally elongated rectangular or frequently broadly ovoid in shape in tangential section, $17-25 \mu$ in vertical and horizontal diameters. Ray cells exhibit abietineous pitting on their tangential horizontal walls, but pits are less conspicuous than those of Planoxylon. Two to six half bordered pits horizontally disposed in one or two rows in a cross field.

Affinity. Although the present specimen exhibits brachyoxylic pattern of bordered pits, it does not belong to Brachyoxylon as it has abietineous pitting on ray cells. It resembles also Metacupressinoxylon in general structures, but differs from the latter in being devoid of wood parenchyma. It is also distinguished from Planoxylon in the absence of wood parenchyma and in having many small pits in a cross field. Cedroxylon is different from the present specimen in having wood parenchyma and often resin canals. In Paracedroxylon, bordered pits mainly separately arranged and abietineous pitting is absent though rarely sporadically present.

Thus the present specimen would be obliged to belong to Protocedroxylon, as it has exhibited brachyoxylic pattern of bordered pits on tracheids and abietineous pitting on ray cells and has been devoid of wood parenchyma and resin canals (see Seward $\left.{ }^{7}\right)$. Three species have been described as Protocedroxylon, $P$. araucarioides Gothan, P. scoticum (Holden) Seward and P. Paronai Negri (see Seward ${ }^{7)}$ ). Among them, $P$. araucarioides from the Jurassic of Spitzbergen and also from The Cretaceous of South Saghalien (Shimakura) ${ }^{4)}$ most closely resembles the present species in the general structures, but differs from the latter in the occurrence of higher rays of 1-35 cells in height and 1-3 pits in a cross field instead of lower rays of 1-6 cells in height and 2-6 pits in a cross field. P. scoticum from the Cretaceous of Scotland also resembles the present species in abundance of the tracheids with cross septa which seem to be tyloses in origin, but is distinguished from the latter by the occurrence of biseriate and heigher rays of 2-20 cells in height and by the absence of bordered pits on tangential walls of the tracheids. P. Paronai from Middle Cretaceous of Iefren, near the Gulf of Tripoli exhibits biseriate bordere dpits by which it can be distinguished distinctly from the present species.

\section{Araucarioxylon sp. (Fig. 4, Plate IV)}

No. 6609 is a piece of secondary wood exhibiting araucarian structure, $5.2 \mathrm{~cm}$ long and $3.1 \mathrm{~cm}$ in diameter, and consisting only of tracheids and rays.

Description. Growth rings absent. Tracheids rectangular or more or less radially elongated square in cross section, $21-27 \mu$ and $20-32 \mu$ in tangential and radial diameter respectively. Tracheids sometimes occluded with brown resinous substances and seemingly appeared to be wood parenchyma. Bordered pits circular or somewhat flattened, contiguously arranged in one row chiefly on radial walls, $9-12 \mu$ in diameter, and with circular pit apertures of $3.5-5 \mu$ in diameter. Sometimes bordered pits alternately arranged in two rows. Small circular, $7-8.5 \mu$ in diameter, bordered pits often contiguously arranged in one row on tangential walls. Rims of Sanio absent. Rays all parenchymatous, always uniseriate, usually 1-4 cells high but rarely higher than 4 in extreme cases, and run at intervals of $3-15,8.2$ on an average, rows of tracheids. Ray cells vertically elongated elliptical in tangential section and $19-22 \mu$ and ca. $12 \mu$ in vertical and horizontal diameters respectively. Tangential and hori- 

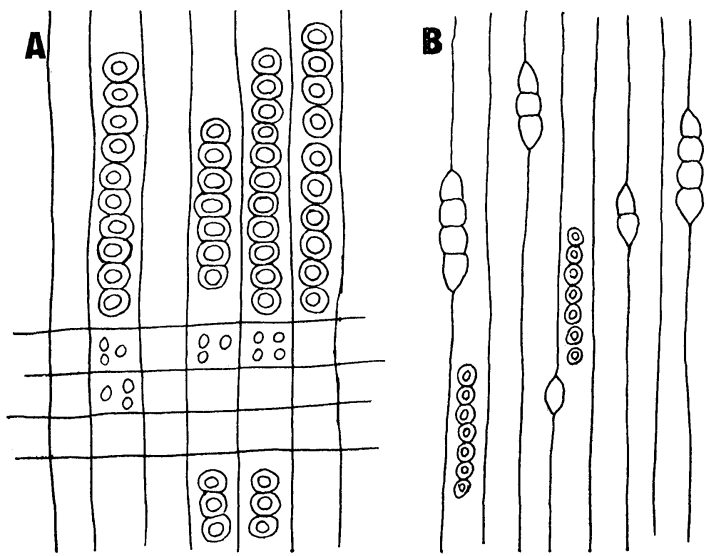

Fig. 4. Araucarioxylon sp.

A : radial section. $B$ : tangential section. Contiguous bordered pits often appear on tangential walls of tracheides.

zontal walls devoid of abietineous pitting. Usually three circular pits, $3-5 \mu$ in diameter, which are evenly distributed in a cross field. Neither wood parenchyma nor resin canals present.

Affinity. The present specimen has apparently exhibited araucarian structures and resembles closely $A$. kiiense Ogura $^{8)}$ in general structures, but differs from the latter in having mostly uniseriate and lower, 1-4 cells high, rays instead of usually biseriate or sometimes triseriate and 1-8 (20) cells high in the latter. Moreover this specimen exhibits small contiguous bordered pits also on tangential walls. These special cases as such are very rare in Araucarioxylon and A. tankoense Stopes and $\mathrm{Fujii}^{9)}$ also exhibits such special condition as this. But $A$. tankoense is distinguished distinctly from the present species by having bordered pits arranged in 2-4 rows, rays of 1-15 cells in height and 4-8 small pits arranged in 2-3 rows in a cross field. Dadoxylon japonicum Shimakura ${ }^{10)}$ has also bordered pits on tangential walls, but differs from the present species as the former has sometimes tracheids with some cross septa and higher rays of 1-25 cells in height. D. sidugawaense Shimakura ${ }^{4}$ differs from the present species in having growth ring, higher rays, chiefly $3-8$ cells in height, wood parenchyma, and horizontally arranged 1-3 pits in a cross field. The present specimen is certainly new to Japan and Far East, but it is difficult to determine whether this specimen is new to science or not, as more than 200 species have been described as Dadoxylon including Araucarioxylon ${ }^{11}$. This specimen may be new species in high probability.

\section{Literatures}

1) Nishida, M., Bot. Mag. Tokyo $80: 383$ (1967).

2) Hollick, A. and Jeffrey, E.C., Mem. New York Bot. Gard. 3: 1 (1909).
3) Torrey, R.E., Mem. Boston Soc. Nat. Hist. 6 (2) : 42 (1923).

4) Shimakura, M., Sci. Rep. Tohoku Imp. Univ. 2nd Ser. 19: 1 (1937). 
5) Stopes, M., Ann. Bot. 30: 111 (1916).

6) Nishida, M., Jap. Journ. Bot. 18:87 (1962).

7) Seward, A.C., Fossil Plants vol. 4. Camb. Univ. Press, London (1919).

8) Ogura, Y., Jap. Journ. Bot. $13: 345$ (1944).
9) Stopes, M. and Fujii, K., Trans. Roy. Soc. London, Ser. B. 201 : 1 (1910).

10) Shimakura, M., Sci. Rep. Tohoku Imp. Univ. 2nd Ser. 18 (3): 267 (1936).

11) Schultze-Motel, J., Geologie $11: 716$ (1962).

摘

要

\section{西田 誠： 銚子産材化石 No. 5}

前報1に引き続いて 4 種の材化石を報告する。そのうち 3 種は明かに新種である.

Brachyoxylon nipponicum sp. nov. はB. notabile に似ているが髄線が 2 列になり，しかも細胞高が 高いことによって区別される.B. raritanense も本種に似ているが，分野に 1-9 個の小眼形の膜孔がある ので本種と区別される.

Planoxylon choshiense sp. nov. は仮道管の切線壁上にも連接する有縁孔を有する点でこの属の他の種 と区別できる. その他髄線の構造にも特徵がある. Protocedroxylon japonicum sp. nov. はスピッツベル ゲンや南カラフトから知られている P. araucarioides に焁もよく似ているが，髄線の細胞高が高く，分野 の膜孔が少いので区別できる. 第4の隀 Araucarioxylon sp. は A. kiiense と似ているが，髄線の細胞 高は低く，かつ常に1列である点がちがう.Dadoxylon sidugawaense にも，年輪がないという他はよく 似ている.（千葉大留学生部） 

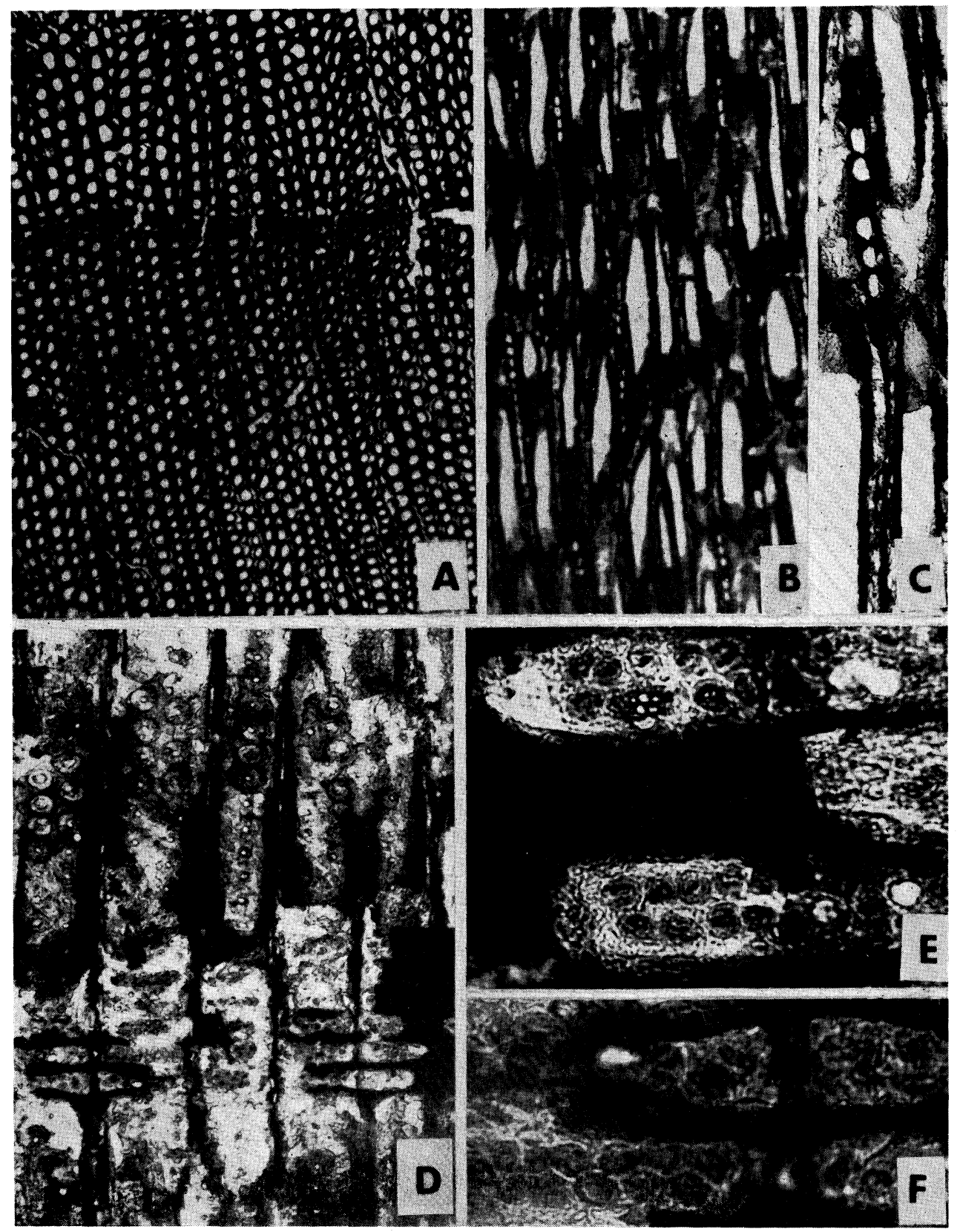

Plate I. Brachyoxylon nipponicum sp. nov.

A : cross section. $\mathrm{B} \& \mathrm{C}$ : tangential sections. D-F : radial sections. $\mathrm{E} \& \mathrm{~F}$ are magnified photographs of cross fields with crowd bordered pits. A, B : $\times 100, \mathrm{C}, \mathrm{D}: \times 150, \mathrm{E}, \mathrm{F}$ : $\times 400$. 

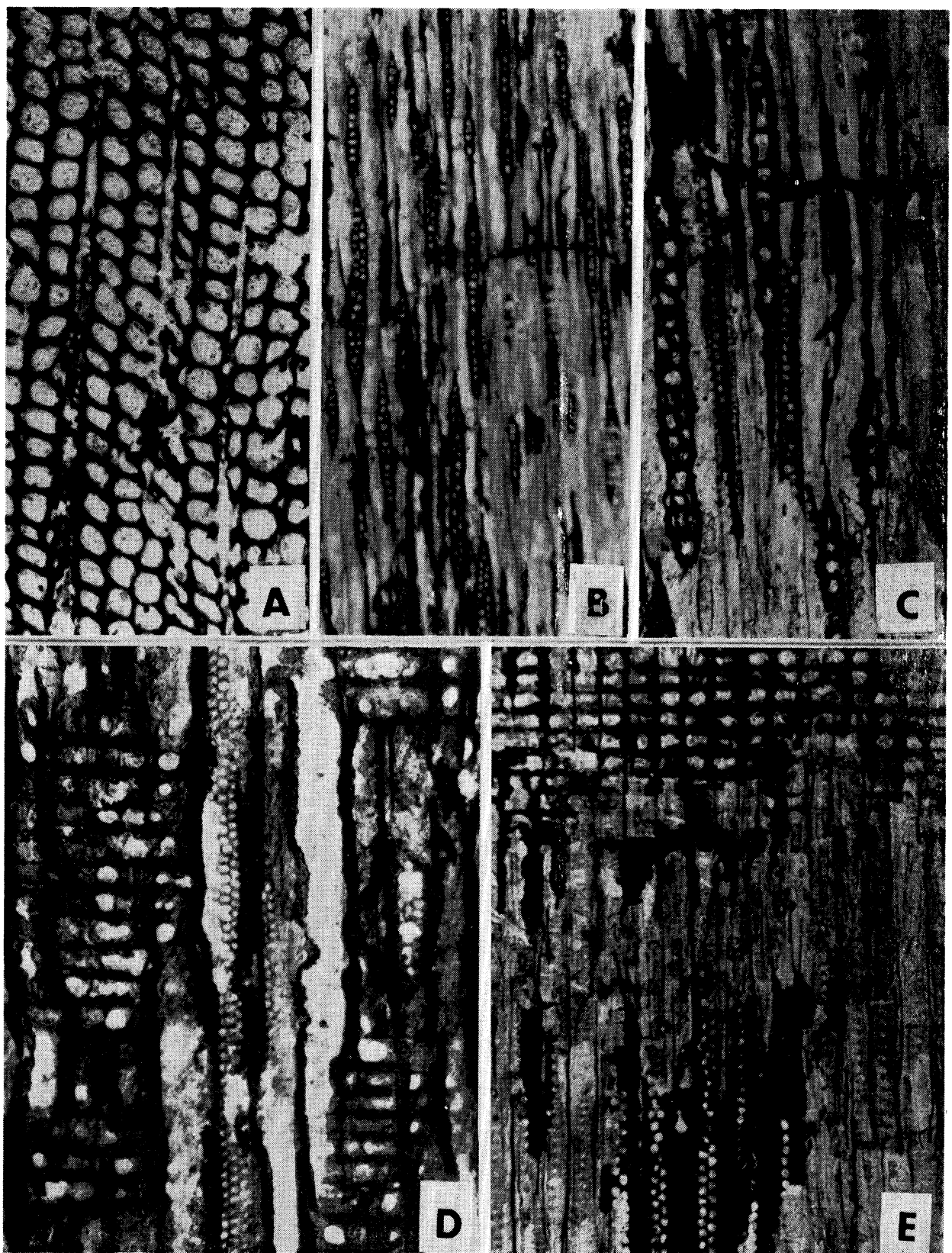

Plate II. Planoxylon choshiense sp. nov.

A : cross section showing abietineous pitting on horizontal walls of ray cells. B \& C: tangential sections. $\mathrm{C}$ is a magnified photograph showing triseriate ray and bordered pits on tangential walls of tracheides. D \& E : radial sections. A, C: $\times 150, B: \times 100$, D, E: $\times 150$. 


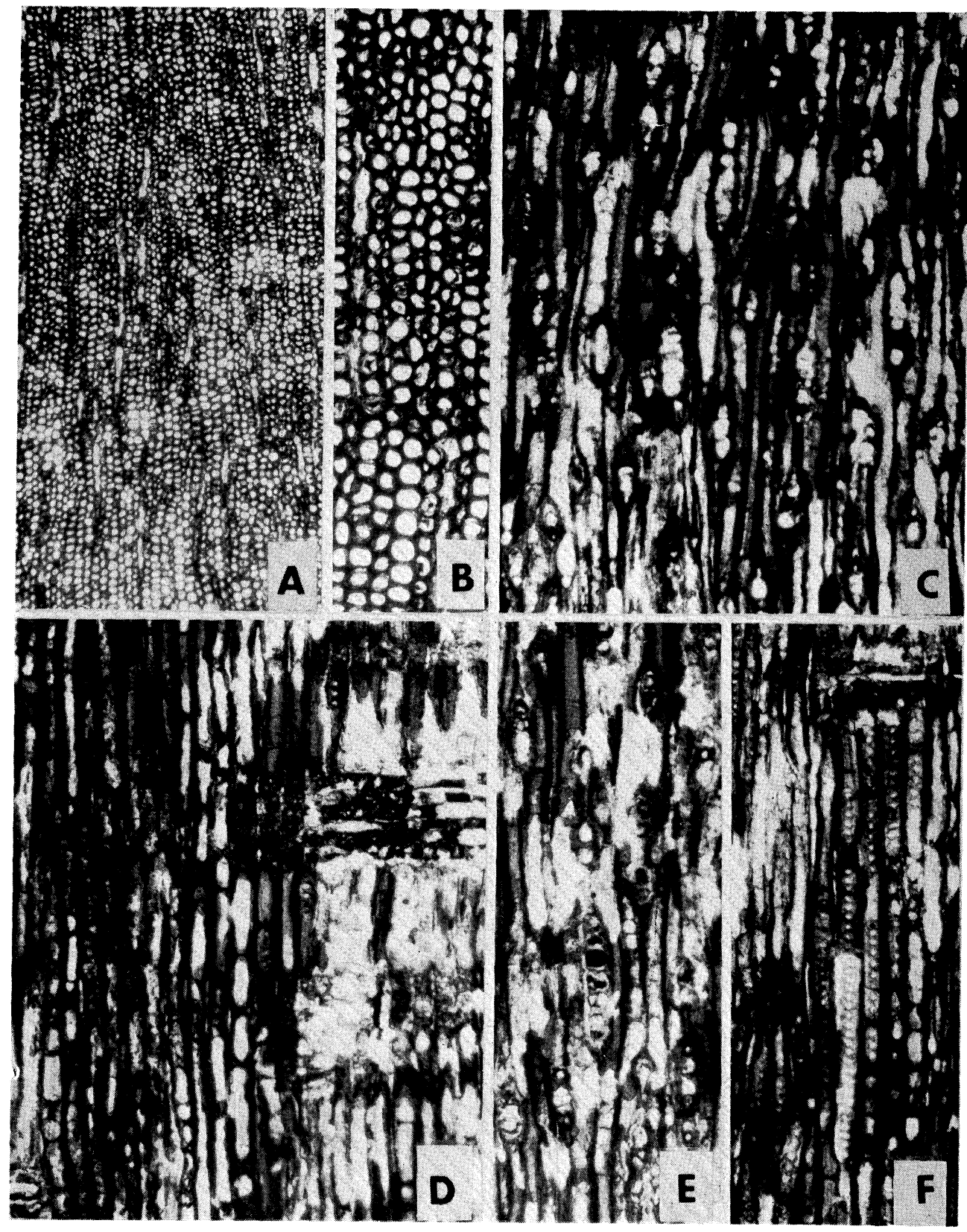

Plate IIJ. Protocedroxylon japonicum sp. nov.

A \& B : cross sections. C \& E : tangential sections. D \& F : radial sections; Tracheids with cross septa are clearly seen in D,E and F. A: $\times 50, B-F: \times 100$. 


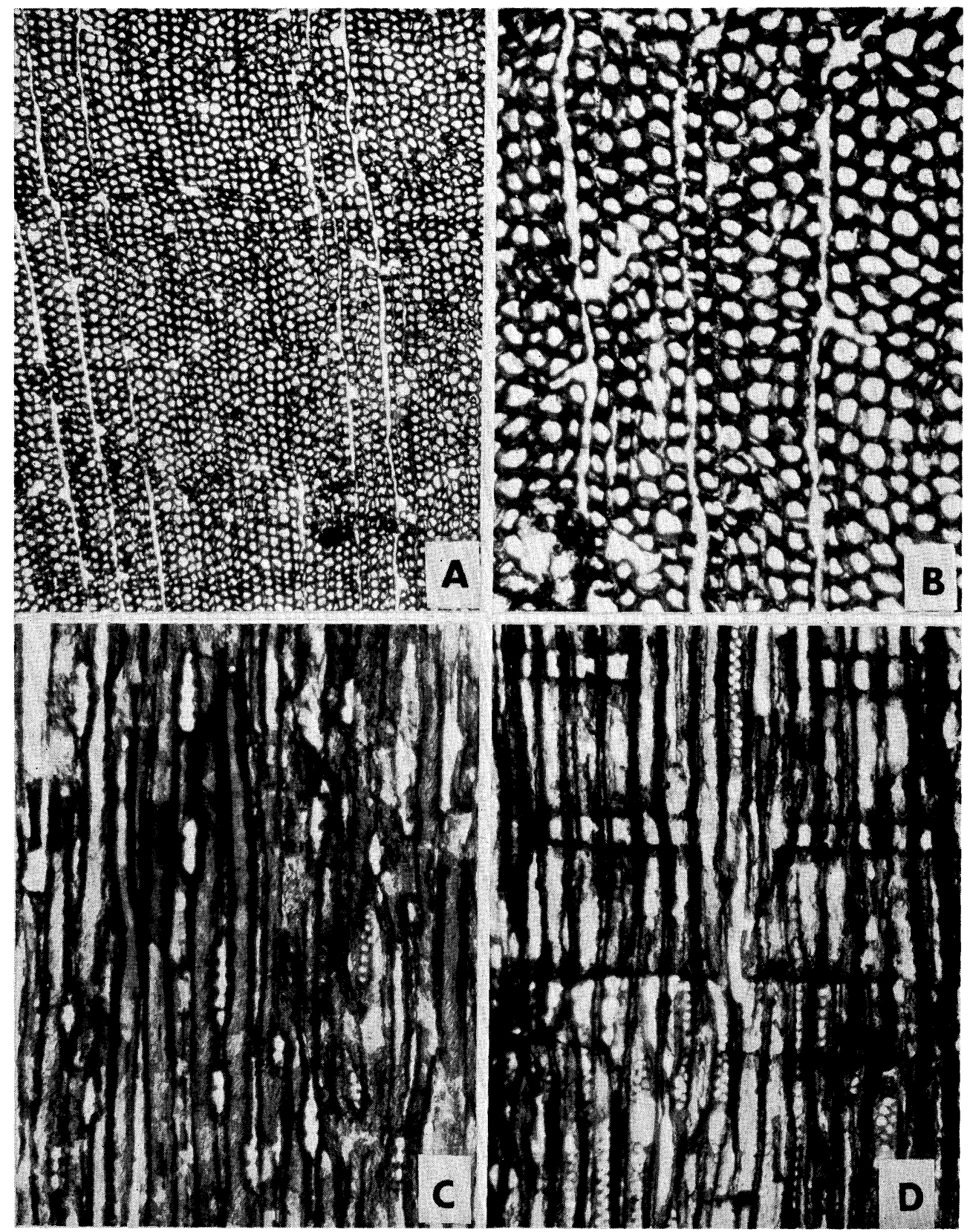

Plate IV. Araucarioxylon sp.

A \& B : cross sections. $\mathrm{C}$ : tangential section. D: radial section. A: $\times 50, \mathrm{~B}-\mathrm{D}: \times 150$. 